\title{
SUOMEN MAATALOUSHISTORIAN PÄÄLINJAT
}

\author{
Arvo M. SoIninen \\ Valtion Yhteiskuntatieteellinen Toimikunta
}

Saapunut 27. 2. 1966

Maatalouden asema maamme talouselämässä on viime vuosikymmeninä kokenut suuren muutoksen. Aina esihistoriallisesta ajasta 1900-luvun alkupuolelle saakka maatalous on ollut Suomen pääelinkeino, josta yli puolet väestöstä sai toimeentulonsa. Lähes vuosisadan verran maatalous on ollut elinkeinona laskusuunnassa ja muut, varsinkin teollisuus noususuunnassa, jos tarkastelun perustaksi ottaa ammatissatoimivan väestön jakautumisen.

Tämä asiantila näyttää vaikuttaneen myös taloushistorialliseen tutkimukseen. Mielenkiinto on ensi sijassa kohdostunut noususuunnassa olevien elinkeinojen kehitykseen. Maatalous on laskusuunnassa olevana saanut jäädä vähemmälle. Maaseudun sosiaalihistoria on kyllä kiinnostanut tutkijoita ja alalta on ilmestynyt korkeatasoisia tutkimuksia (7). Syynä tutkimuksen suuntautumiseen tälle alalle lienevät olleet maaseudun kipeät sosiaaliset ongelmat tämän vuosisadan alussa. Sen sijaan puhtaasti taloushistoriallisia erikoistutkimuksia on maataloushistoriamme alalta niukasti ja yleisesitys puuttuu kokonaan. ${ }^{1}$

Näin ollen on ymmärrettävää, että maataloushistoriamme suuret linjat eivät vielä ole täysin selkiytyneet. Tähän asiantilaan vaikuttanee eniten se, että maatalouden eri sektoreita ja viljelymenetelmiä on tarkasteltu liiaksi irrallisina. Kaiken maataloudellisen toiminnan perusyksikkö, maatilan muodostama talouskokonaisuus, maatilatalous, on jäänyt syrjemmälle. Kuitenkin juuri maatilan taloudellisten toimintojen summa määrää sen asukkaiden toimeentulon. Riittävä yleiskuva maatalouskehityksestä saadaan vain silloin, kun maatalouden eri puolia tarkasteltaessa otetaan huomioon niiden asema ja merkitys maatalouden kokonaiskehityksessä.

\section{Maatalouden metsätalous-sektori}

Suomen maatilatalouden kolmen pääsektorin, maanviljelyn, karjatalouden ja metsätalouden, osuus tilan taloudessa on aikojen kuluessa tuntuvasti vaihdellut

${ }^{1}$ Laajimman alan peittävä esitys on Gösta Grotenfeltin tutkimus perinnäisen maatalouden viljelymenetelmistä (3). - Väinö Voionmaan suppea katsaus Suomen maataloushistoriaan (29) on vanhentunut. 
ja tämä vaihtelu muodostaa oleellisen osan maatalouskehitystä. Suomen maatalouden erikoispiirteenä on metsätalouden suuri osuus maatilataloudessa. Tämä ei ole vain viimeisen sadan vuoden aikaiseen puutavaratalouteen rajoittuva ilmiö, vaan ulottuu kauas maataloutemme varhaisvaiheisiin asti.

Metsätalouden merkitys suomalaisessa maataloudessa oli jo esihistoriallisella ajalla suunnilleen sama kuin nykyisinkin, mutta sen laatu oli toinen. Metsän hyväksikäyttö tapahtui erätalouden muodossa. Keskiajan kuluessa erätalous ja samalla metsän osuus maatilataloudessa menetti taloudellista merkitystään ja uuden ajan alussa metsän osuus maatilataloudessa oli jo varsin vähäinen. Noin 300 vuoden ajan 1500-luvulta 1800-luvulle ei metsällä ollut suurtakaan sijaa suomalaisessa maatilataloudessa, vaan maanviljelijän oli rakennettava taloutensa pääasiassa maanviljelyn ja karjanhoidon varaan. Vasta uudenaikaisen puutavaratalouden synty 1800-luvulla toi metsätalouden jälleen oleelliseksi osaksi maatilataloutta.

Metsätalouden ensimmäinen muoto, erätalous, oli turkismetsästystä ja kalastusta $(6,13,15,15,20,27,28)$. Varsinkin turkismetsästyksen taloudellinen merkitys oli suuri, sillä turkisten ulkomaista kysyntää näyttää aina riittäneen kauppaolojen suurista muutoksista huolimatta. Turkismetsästys oli suomalaiselle maanviljelijälle samanlainen varallisuuden lähde kuin metsänmyynti nykyään. Suomalaiselle eränkäynnille onkin ominaista, että se liittyy kiinteästi maanviljelyyn ja siten maatilatalouden piiriin. Samat miehet tai ainakin saman talon miehet viljelivät kaskiaan ja peltojaan sekä kävivät erää. Metsästysmaita ja kalavesiä, neräsijoja», pidettiin taloon kuuluvina tiluksina kuten kaskimetsiä ja peltoja siitä huolimatta, että ne saattoivat olla yli $200 \mathrm{kmn}$ päässä tilan talouskeskuksesta.

Keskiajan lopulla asutuksen leviäminen ja ryöstöpyynti näyttävät vähentäneen turkisriistan niin vähiin, että erätalous menetti entisen merkityksensä maatilatalouden osana ja 1500-luvulla erätalous oli käytännöllisesti katsoen lopussa Eteläja Keski-Suomessa. Maanviljelijän oli rakennettava taloutensa pääasiassa maanviljelyn ja karjanhoidon varaan.

Metsätalous koko tosin uuden nousun 1600-luvulla, mutta se jäi hyvin lyhytaikaiseksi. Tämä tapahtui nyt tervatalouden muodossa $(10,25)$. Tervanpolton kannattavaisuus oli kuitenkin pitkien kuljetusmatkojen ja runsaan tarjonnan vuoksi heikko. Kun Uudenkaupungin rauha 1721 katkaisi kulkuyhteydet Saimaalta Suomenlahdelle kävi tervanpoltto kannattamattomaksi suurimmassa osassa Sisä-Suomea. Vain Pohjanmaalla oli mahdollista jatkaa tervanpolttoa. 1700-luvulla ja 1800 luvun alkupuolella metsän merkitys maatilataloudessa rajoittui etupäässä kotitarvepuiden ottoon ja karjan laiduntamiseen. Tilanne oli Suomessa siis sama kuin Euroopan maataloudessa yleensä, mutta meidän oloissamme maatilatalouden rakentuminen melkein yksinomaan maanviljelyn ja karjanhoidon varaan merkitsi sen taloudellisen toimintakentän tuntuvaa supistumista.

\section{Maatalouden karjatalous-sektori}

Maatalouden toisen tärkeän sektorin, karjatalouden, funktio tilan talouskokonaisuudessa on myös eri aikoina tuntuvasti vaihdellut. Maatalouden tuotantosuunnan ollessa viljanviljelyvaltainen, karjalla oli merkitystä lähinnä vain lannan tuot- 
tajana peltoja varten, joiden lannoitus oli kokonaan karjalannan varassa. Varsinaiset karjantuotteet, maito ja liha, tulivat tärkeiksi vasta 1800 -luvulla, kun olosuhteet johtivat muutoksiin maatalouden tuotantosuunnassa.

Viljanviljelyvaltaisella kaudella oli karjataloudessa pääasiana karjan mahdollisimman suuri lukumäärä, niin että lantaa saataisiin riittävästi pellon lannoittamiseen. Lannan tarve pysyi kuitenkin yleensä sen tuotantoa suurempana, joten karjaa pyrittiin pitämään enemmän kuin rehuvarat sallivat. Ruokinta jäi tällöin luonnollisesti heikoksi ja karjaa pidettiin äärimmäiseen nälkiintymisrajaan saakka. Karjan laatu oli tällöin huonoa, maidon ja lihan tuotanto vähäistä $(3,12,1,26)$.

Kaskiviljelyalueilla karjanhoidon asema oli jonkin verran toisenlainen kuin peltoviljelyalueella. Kun karjaa ei tarvittu lannan tuottajana, oli maidon ja lihan tuotanto etualalla. Karjaa pidettiin vähemmän ja ilmeisesti ruokittiin paremmin. Laadultaan paras karja näyttääkin olleen kaskialueilla (3).

Karjanhoidon aseman muutos 1800-luvulla liittyy yleiseen maataloussuhdanteiden muutokseen. Kehitys kulki Suomessakin yleiseurooppalaista linjaa viljanviljelyn kannattavuuden heiketessä, mutta karjantuotteiden hintasuhteiden pysyessä edullisina. Suomessa kuljetusyhteyksien paranemisella oli vielä suurempi merkitys kuin tiheämmin asutuissa maissa. Karjatalouden merkityksen kasvu näyttää alkaneen Suomessa verraten varhain yleiseurooppalaiseen kehitykseen verrattuna. Osittain tämä näyttää johtuneen jo ennen 1800-luvun puoliväliä alkaneesta venäläisen viljan tuonnista, mutta ehkä vielä enemmän kaski- ja peltoviljelyn murroksen aiheuttamasta kriisitilasta Itä-Suomen maataloudessa. ${ }^{1}$

Voinvienti muodostui 1800-luvun loppupuolella karjatalouden perustaksi, joten karjatalous kehittyi yksipuolisesti lypsykarjavaltaiseen suuntaan (18). Vasta ensimmäisen maailmansodan ajan kovat kokemukset herättivät pyrkimyksen karjatalouden monipuolistamiseen ja paremman tasapainon saavuttamiseen karjatalouden ja viljanviljelyn välillä. Viime aikojen kehitykselle on kuitenkin ollut luonteenomaista, että pyrkimys tasapainoon ei niinkään ole ollut tilakohtaista, vaan suuremmissa puitteissa tapahtuvaa. Yksityisen tilan tuotannossa on päinvastoin havaittavissa yhä suurempaa erikoistumista.

\section{Maatilatalouden maanviljely-sektori}

Metsätalouden ja karjatalouden merkitys maatilataloudessa on maassamme nykyisin niin suuri, että kyseenalaista on, voidaanko varsinaista maanviljelyä enää pitää maatalouden pääsektorina. Sen sijaan perinnäisen maatalouden aikana esihistorialliselta ajalta aina 1800-luvulle asti maanviljely oli kiistattomasti pääsektorin asemassa ja tuotantosuunta viljanviljelyvaltainen.

Teknisesti tämä aika oli maanviljelyssä perinnäisten viljelysmenetelmien aikaa. Viljelytekniikka meni perintönä isältä pojalle ja tekniset parannukset tulivat vain hitaasti yleiseen käyttöön. Tietoyhteydet olivat puutteellisia ja kaikkeen uuteen suhtauduttiin epäillen. Tähän asennoitumiseen oli reaalistakin perustaa: alhaisen elintason vallitessa epäonnistuneet kokeilut saattoivat olla hyvinkin kohtalokkaita.

${ }^{1}$ Esitys perustuu alkuperäisaineistoon, jonka kirjoittaja on koonnut Suomen maatalouskehitystä 1720 -luvulta 1870 -luvulle koskevaa tutkimusta varten. 
Sen sijaan tuttuja rinnakkaismenetelmiä vaihdeltiin tarpeen mukaan hyvinkin paljon. Oleellisinta maatalouskehityksessämme ei ole ollut tekninen kehitys, vaan taloudellisen toiminnan painopisteen siirtyminen maatilataloudessa toimintasektorien ja rinnakkaismenetelmien välillä. Tässä mielessä maatalouskehitys on maassamme jatkuvasti ollut dynaamista.

Rinnakkaisten viljelysmenetelmien käyttöä samalla maatilalla on pidettävä eräänä perinnäisen maanviljelyn tärkeimmistä ominaispiirteistä. ${ }^{1}$ Näitä menetelmiä oli neljä: kaskiviljely, peltoviljely, niittyviljely ja suoviljely, joista kukin vaati oman tiluslajinsa ja oman viljelytekniikkansa. Kun maataloushistoriallisessa kirjallisuudessa kutakin viljelymenetelmää on tarkasteltu yleensä erikseen, ei useinkaan ole kiinnitetty huomiota siihen tosiseikkaan, että kaikki ne kuuluivat saman maatilatalouden piiriin. Kaikki neljä menetelmää saattoivat olla yhtaikaisesti käytössä samalla tilalla. Painopiste oli tavallisesti kylläkin yhdellä menetelmällä, mutta myös muut menetelmät olivat yleensä tunnettuja ja jossain määrin myös käytössä. Vain harva talo kykeni tulemaan toimeen kokonaan yhden viljelymenetelmän varassa.

Tärkeimmät rinnakkaismenetelmät olivat luonnollisesti kaskiviljely ja peltoviljely ja niiden välisten suhteiden muuttumisella on ollut suuri merkitys maatalouskehityksessämme. Siirtymisen pääsuunta on ollut kaskiviljelystä peltoviljelyyn, mutta päinvastaistakin kehitystä on havaittavissa. Jos peltoviljelyä harjoittanut talonpoika siirtyi uudisasukkaaksi asumattomalle erämaaseudulle, siirtyi hän samalla peltoviljelystä kaskiviljelyyn. Taloudellisesti tämä ei ollut mikään taka-askel, sillä luonnontilassa olleissa metsissä käytetty kaskiviljelyn laji, huuhtakaski, oli tuottoisin kaikista perinnäisen maanviljelyn tuntemista viljelymenetelmistä (19, 20). Huuhtakasken viljely oli kuitenkin mahdollista vain laajoilla metsäseuduilla, joten sen käyttö rajoittui etupäässä uudisasutusaikaan.

Tietomme kaskiviljelyn ja peltoviljelyn suhteissa tapahtuneista siirtymistä niin ajallisesti kuin paikallisesti ovat vielä yllättävän hatarat. Kun kaskiviljelyä ja peltoviljelyä on harjoitettu rinnan suurimmassa osassa maata, on kaski- ja peltoviljelyalueiden raja vedettävä sen mukaan kummalla puolen viljelyn painopiste maatilataloudessa oli. Vaikka onkin mahdollista sanoa, että Länsi-Suomi oli peltoviljelyaluetta ja Itä-Suomi kaskiviljelyaluetta, rajan vetäminen niiden välille riittävällä tarkkuudella ja tässä rajassa tapahtuneiden muutosten seuraaminen on vielä ylivoimainen tehtävä. Ilmeistä kuitenkin on, että raja on ollut jatkuvassa liikkeessä ja peltoviljelyalueen sisään on jäänyt kaskiviljelysaarekkeita. Eräs tällainen saareke näyttää 1700-luvun alkupuolella olleen Hämeen ja Uudenmaan rajalla Lopen-Hausjärven seuduilla. Paikallishistoriallisella tutkimuksella on tässä kohden vielä paljon tehtävää perusaineiston hankkijana.

Alueellisesti laajin yhtaikainen siirtyminen kaskiviljelyksestä peltoviljelyyn on tapahtunut Savossa ja Karjalassa 1800-luvulla. Siirtyminen oli niin laajamittaista ja nopeata, että Itä-Suomen maatalous näyttää joutuneen vaikeaan kriisitilantee-

\footnotetext{
${ }^{1}$ Kirjallisuudessa ei tähän ole kiinnitetty paljoakaan huomiota. Isojakoasiakirjat (Maanmittaushallituksen ja Maanmittauskonttorien arkistot) ja kruunutilojen katselmuspöytäkirjat (Lääninhallitusten arkistot) osoittavat selvästi rinnakkaismenetelmien käytön samalla tilalla olleen aivan yleistä.
} 
seen. Peltoviljelyn laajeneminen ei ilmeisestikään kyennyt korvaamaan kaskiviljelyn supistumisen aiheuttamaa viljasadon vähennystä, vaan Savo ja Karjala muodostuivat alituotantoalueiksi. Tilannetta pahensi vielä huonojen satovuosien tiheä toistuminen vv. 1830 ja 1870 välisinä neljänä vuosikymmenenä. Maatalousväestön eri kerrokset selvisivät viljelymenetelmien murroksesta eri tavoin. Pahiten kärsi irtain loisväestö, joka kaskiviljelyn mukana menetti huomattavan osan toimeentulomahdollisuuksistaan. ${ }^{1}$

Kehitystä ja muuttumista tapahtui myös pääviljelymenetelmien sisällä. Mikään näistä neljästä menetelmästä ei ollut yhtenäinen, vaan jakaantui useisiin alalajeihin ja muunnoksiin. Rajoitun seuraavassa peltoviljelyn alalle. Huomattavin muutos siinä oli siirtyminen kaksivuoroviljelystä kolmivuoroviljelyyn. Vielä 1600luvulla oltiin koko maassa kaksivuoroviljelyn kannalla. Länsi-Suomen kaksivuoroviljely 1600-luvulla on ollut jo vanhastaan tunnettu tosiasia, mutta Itä-Suomen osalta maataloushistoriallisessa tutkimuksessa on esiintynyt eriäviä käsityksiä. Savon vanhimmat tiluskartat 1600 -luvun puolivälistä osoittavat kuitenkin selvästi kaksivuoroviljelyn olleen tällöin käytössä itäisen Suomenkin alueella. Sen sijaan jo 1700-luvun lähteistä ilmenee, että peltoviljely Itä-Suomessa oli siirtynyt kolmivuoroviljelyn kannalle, ja että tämä menetelmä oli leviämässä länttä kohti. ${ }^{2}$ Kolmivuoroviljely kohtasi kuitenkin Länsi-Suomessa pahan esteen: heikon muokkaustekniikan, joka jarrutti sen leviämistä raskaille savimaille. Keski-Euroopan savimaiden tehokas mutta raskas muokkausväline, ratasaura, ei levinnyt koskaan Suomeen saakka, vaan täällä käytettiin aina 1800-luvulle saakka ikivanhaa heikkotehoista koukkuauraa. Huonon muokkauksen tähden rikkaruohojen kurissapito edellytti tiheää kesannoimista. Kesannoimisvälin pidentäminen yhdestä vuodesta kahteen näyttää jo päästäneen rikkaruohot valloilleen. Vielä 1800-luvun puolella monet yritykset siirtyä kolmivuoroviljelyyn Länsi-Suomen savimailla epäonnistuivat tästä syystä. Lisäksi kolmivuoroviljelyn edut olivat pienimmät syysruisvaltaisessa viljelyssä, jollaista Länsi-Suomen viljanviljely oli. Tilanne muuttui oleellisesti vasta 1800-luvun jälkipuoliskolla, jolloin rautaiset kääntöaurat tekivät kesannon harventamisen mahdolliseksi ja rehuviljan tarve lisäsi kevätviljojen viljelyalaa. Tällöin oli kuitenkin kolmivuoroviljely jo väistymässä uusien viljelymenetelmien tieltä.

\section{Uudenaikaisen maatalouden synty ja maatalousväestön asema}

Maataloudessa tapahtui 1800-luvun jälkipuoliskolla muutoksia, jotka merkitsivät kokonaan uuden kehityskauden alkamista. Metsätalous tuli jälleen tärkeäksi osaksi maatilataloutta ja maatalouden tuotantosuunta vaihtui viljanviljelyvaltaisesta karjatalousvaltaiseksi. Myös itse maanviljely koki suuren muodonmuutoksen. ${ }^{3}$

\footnotetext{
${ }^{1}$ Esitys perustuu alkuperäisaineistoon, jonka kirjoittaja on koonnut Suomen maatalouskehitystä 1720-luvulta 1870-luvulle koskevaa tutkimusta varten.

${ }^{2}$ Kirjallisuuden $(1,12,21,23,26)$ lisäksi alkuperäisiä tiluskarttoja 1600- ja 1700-luvuilta (Maanmittaushallituksen arkisto).

${ }^{3}$ Varsinaisen maanviljelyn suuresta teknisestä kehityksestä 1800-luvun lopulla ja tällä vuosisadalla ei ole vielä yhtenäistä esitystä. Lyhyitä katsauksia ovat kirjoittaneet K. J. Ellilä (2), J. E. Sunila (23) ja K. T. Jutila (9).
} 
Vanha rinnakkaismenetelmäjärjestelmä hävisi. Kaskiviljely ja niittyviljely lakkasivat vähitellen ja suoviljely sulautui peltoviljelyyn. Maanviljely on nyt pääasiassa peltoviljelyä. Viljelytekniikka ei ole enää perinnäistä, vaan tieteellisen tutkimustyön käytännölliseen sovellutukseen perustuvaa. Ihmistyöstä on vähitellen siirrytty yhä enemmän konevoimaan.

Kaikki nämä muutokset toivat mukanaan uusia vaatimuksia niin maatalouden tuotantoyksiköille, maatiloille, kun myös maataloudessa työskentelevälle väestölle. Tilayksiköiden ja maatalousväestön rakenteen mukauttaminen maatalouden nopeaan teknillistaloudelliseen kehitykseen on tullut erääksi maatalouden keskeisimmistä ongelmista. Viimeisen sadan vuoden maatalouskehitykselle näyttää olevan luonteenomaista taloudellisten ja sosiaalisten tekijöiden entistä läheisempi vuorovaikutus, mutta samalla myös taloudellisen ja sosiaalisen kehityksen toistuva ristiriitaisuus.

Maatalouden suuret rakennemuutokset vaikuttivat eri tavoin maatalousväestön eri kerroksiin. Lypsykarjavaltaisen maatalouden kaudella ennen ensimmäistä maailmansotaa olivat parhaimmassa asemassa itsenäiset maanviljelijät, joilla oli mahdollisuuksia metsätaloudesta saamansa pääoman turvin toteuttaa uudistuksia maanviljelyssään ja karjataloudessaan (11). Myös pohjakerros, irtain maataloustyöväki, hyötyi uudesta maatalouskehityksestä (7). Metsätalous avasi tälle väestönosalle uusia työmahdollisuuksia metsätöissä ja puunjalostusteollisuuden palveluksessa. Sen elintaso, vaikka olikin hyvin alhainen, oli kuitenkin jatkuvasti noususuunnassa. Torpparit sen sijaan joutuivat uuden kehityksen jalkoihin. Torpparilaitos ei kyennyt mukautumaan maatalouden uuteen teknillistaloudelliseen rakenteeseen ja menetti näin ollen taloudellisen olemassaolon oikeutensa ${ }^{1}(5,7,9,17)$.

Perinnäisen maatalouden aikana torpparilaitos täytti tyydyttävästi taloudellisen funktionsa maataloudessa eikä torpparin sosiaalista asemaakaan voi pitää 1700 luvulla mitenkään huonona. 1800-luvulla sekä taloudellinen että sosiaalinen kehitys kulkı torppareille epäedulliseen suuntaan, joskin vasta vuosisadan lopun maataloudelliset uudistukset muodostuivat heille tuhoisiksi. Torppareiden käyttö uudessa maanviljelyssä ja karjataloudessa osoittautui kannattamattomaksi ja heidän metsänkäyttönsä maatilataloudelle suorastaan vahingolliseksi. Torpparilaitos kuului niin kiinteästi perinnäiseen maatalouteen, että se oli uusissa oloissa pakko tavalla tai toisella purkaa. Torpparien irtisanominen olisi ollut maatilatalouden kannalta tarkoituksenmukainen toimenpide, mutta sen sosiaaliset seuraukset suorastaan katastrofaaliset, koska maan talouselämä ei olisi kyennyt sijoittamaan näin vapautuvaa työvoimaa. Irtisanomisen pelottavat sosiaaliset seuraukset viivyttivät torpparilaitoksen purkamista ja lopputuloksena oli torppien itsenäistäminen v. 1918. Ratkaisulla saavutettiin suurempi sosiaalinen kuin taloudellinen hyöty ja sen toimeenpanotapa ennakoi uutta taloudellisten ja sosiaalisten tekijöiden konfliktia maatalouden kehityksessä.

Kun maatalousoloja päästiin Suomen itsenäistyttyä järjestämään, oli sosiaalisista ja poliittisista syistä ihanteena mahdollisimman suuri itsenäinen maanviljelijä-

\footnotetext{
${ }^{1}$ Tutkimus on kiinnittänyt päähuomion torpparilaitokseen yhteiskunnallisena ilmiönä. Sen sijaan torpparilaitoksen maataloudellinen asema ja merkitys on saanut varsin vähän huomiota osakseen.
} 
väestö. Keinona sen saavuttamiseen nähtiin pienviljelyn edistäminen. Pienviljelyn katsottiin myös olevan kansantaloudellisesti edullista, viljelyintensiteetti oli pientiloilla suurempi kuin isompikokoisilla (22). Tanskan hyvin menestynyt pienviljely näyttää huomattavassa määrin olleen esikuvana, sillä 1890-luvulta 1920-luvulle Suomesta käytiin ahkerasti Tanskassa oppia hakemassa. Pienviljelyn paras aika oli 1920-luvulla kuitenkin jo lopullaan, sillä maanviljelyn tekninen kehitys oli kulkemassa pienviljelylle epäedulliseen suuntaan. Koneellistaminen oli johtamassa kannattavan perheviljelmän minimikoon kasvuun. Vaikka jäljestäpäin katsoen pienviljelyn edistämisessä taloudelliset ja sosiaaliset tekijät olivat ristiriidassa keskenään, eivät aikalaiset ilmeisestikään tätä ristiriitaa nähneet, vaan usko pienviljelyn jatkuvaan taloudelliseen elinvoimaisuuteen oli yleinen (22).

Kolmannen kerran maataloudelliset ja sosiaaliset näkökohdat joutuivat vastakkain 1940-luvun pika-asutuksessa (24). Vaikka tilojen pirstomisen taloudelliset haittavaikutukset tajuttiin jo melko yleisesti, sosiaaliset näkökohdat painoivat sodan aiheuttamassa pakkotilanteessa verrattomasti enemmän. Täten sosiaaliset näkökohdat taas kerran voittivat maatilataloudelliset tekijät ja johtivat tilakoon jatkuvaan pienenemiseen. Ristiriita teknisen kehityksen vaatimusten kanssa on tullut yhä suuremmaksi ja liian pienestä tilakoosta on tullut nykyhetken maataloutemme polttavin taloudellinen ongelma.

\section{Yhteenveto}

Suomen maatalouden historia on ollut viljelijän kamppailua toimeentulonsa puolesta vaihtelevissa olosuhteissa. Maatilatalouden rakennemuutokset ja viljelymenetelmien vaihtaminen ovat olleet tärkeitä keinoja maanviljelijän koettaessa mukautua alati liikkeellä olevaan taloudelliseen kehitykseen. Perinnäisen maatalouden kaudella — esihistoriallisen ajan lopulta 1800-luvulle — tekninen kehitys oli varsin hidasta, mutta nopeampaa kehitystä tapahtui taloudellisen toiminnan alalla maatilatalouden painopisteen siirtyessä jatkuvasti sektorilta toiselle tai rinnakkaisesta viljelymenetelmästä toiseen. Käsitys maatalouskehityksemme staattisesta luonteesta perinnäisen maatalouden kaudella, joka perustuu yksipuolisesti teknisen kehityksen hitauteen, osoittautuu näin ollen harhakuvaksi.

Viimeisen sadan vuoden aikana maatalouskehityksen luonne on suuresti muuttunut. Kehitykselle on ollut luonteenomaista nopeasti edistyvä maataloustekniikka ja siirtyminen omavaraistaloudesta vaihdantatalouteen. Seurauksena on ollut sopeutumisvaikeuksia sekä maatalouden tuotantoyksiköille, maatiloille, että maatalousväestölle. Huomattavalta osalta näistä sopeutumisvaikeuksista johtuu, että maatalouden taloudellisen ja sosiaalisen kehityksen välillä on ollut kitkaa ja maatalouden tuottavuuden kasvu on jäänyt jälkeen yleisestä taloudellisesta kasvusta.

KIRJALLISUUS

(1) Alanen, Aulıs J. 1949 Etelä-Pohjanmaan talouselämä 1721-1809. Etelä-Pohjanmaan historia IV.

(2) ElliLÃ, K. J. 1957. Maatalouspolitiikkamme. 
(3) Grotenfelt, Gösta 1899. Det primitiva jordbrukets metoder i Finland under den historiska tiden.

(4) - 1906. Tietoja Suomen maitotalouden kehityksestä.

(5) Gylling, Edvard 1909. Suomen torpparilaitoksen kehityksen pääpiirteet Ruotsin vallan aikana.

(6) JaAkкola, Jalmari 1923. Pirkkalaisliikkeen synty.

(7) Jutikkala, Eino 1942 ja 1958. Suomen talonpojan historia.

(8) - - 1961. Uskonkappaleita ja tosiasioita. Suomalainen Suomi 9.

(9) Jutila, K. T. 1936. Suomen maatalous ja maatalouspolitiikka 20. vuosisadalla.

(10) Kalla, E. E. 1931. Pohjanmaa ja meri 1600- ja 1700-luvuilla.

(11) KUUSANMÄKI, LAURI 1936. Kulutustavaroiden leviäminen maalaisväestön keskuuteen. Suomen kulttuurihistoria IV.

(12) LuUкко, Armas 1957. Elinkeinot. Hämeen historia II: 1.

(13) - 1950. Keskiaika ja 1500-luku. Etelä-Pohjanmaan historia I.

(14) - 1954. Pohjois-Pohjanmaan ja Lapin keskiaika ja 1500-luku Pohjois-Pohjanmaan historia II.

(15) - - 1956. Suomen erätalous uuden ajan alussa. Suomal. tiedeakat., esitelmät ja pöytäkirjat.

(16) NiıtemaA, Vılнo 1955. Hämeen keskiaika. Hämeen historia I.

(17) Rasila, Viljo, 1961. Suomen Torpparikysymys vuoteen 1909.

(18) Srmonen, SePPo 1949. Lypsykarjavaltainen maataloudellinen tuotantojärjestelmä Suomessa.

(19) Soininen, Arvo M. 1960. Burn-beating as the technical basis of colonisation in Finland in the 16th and 17th centuries. Scand. Econ. Hist. Rew. vol. VII, N:o 2.

(20) - - 1961. Pohjois-Savon asuttaminen keski-ja uuden ajan vaihteessa.

(21) Sunila, J. E. 1922. Peltoviljelysjärjestelmät ja niiden kehitys. Oma maa (2. laitos) III.

(22) $\quad-1$ 1922. Viljelmien suuruussuhteet. Suomen maatalous I.

(23) - -1908 . Vuoroviljelys- ja koppeliviljelysjärjestelmät Suomessa.

(24) Vennamo, Veikкo 1958. Siirtoväen asuttaminen. Oma maa (3. laitos) I.

(25) Vilkuna, KustaA 1935. Suomen päävientitavara terva. Suomen kulttuurihistoria III.

(26) - - 1935. Varsinais-Suomen kansanomaisesta taloudesta. Varsinais-Suomen historia III.

(27) Voı́nмaA, VÄıNö 1947. Hämeen eräkausi.

(28) - - 1915. Suomen karjalaisen heimon historia.

(29) - - 1922. Suomen maatalouden kehityskaudet. Suomen maatalous I.

S U M M A R Y:

THE MAIN FEATURES OF AGRICULTURAL HISTORY IN FINLAND

Arvo M. SoINinen

\section{Research Council of Social Sciencies}

The study on the history of agriculture in Finland deals chiefly with the social history of rural areas in the country. Only minor emphasis is placed on the actual economic aspect of agricultural history. Moreover, the various sectors of agriculture and the different farming practices are generally treated separately without sufficient consideration being taken of the farm proper as the basic unit of agricultural economic activity.

The writer examines the contribution made by the different sectors of Finnish farming economy in the development of agriculture and comes to the conclusion that the economic emphasis has constantly shifted between the different branches of agriculture and different methods of farming. From the standpoint of over-all farm economy, the development of agriculture in Finland has by no means been as slow as has generally been believed on the basis of purely technical progress. 